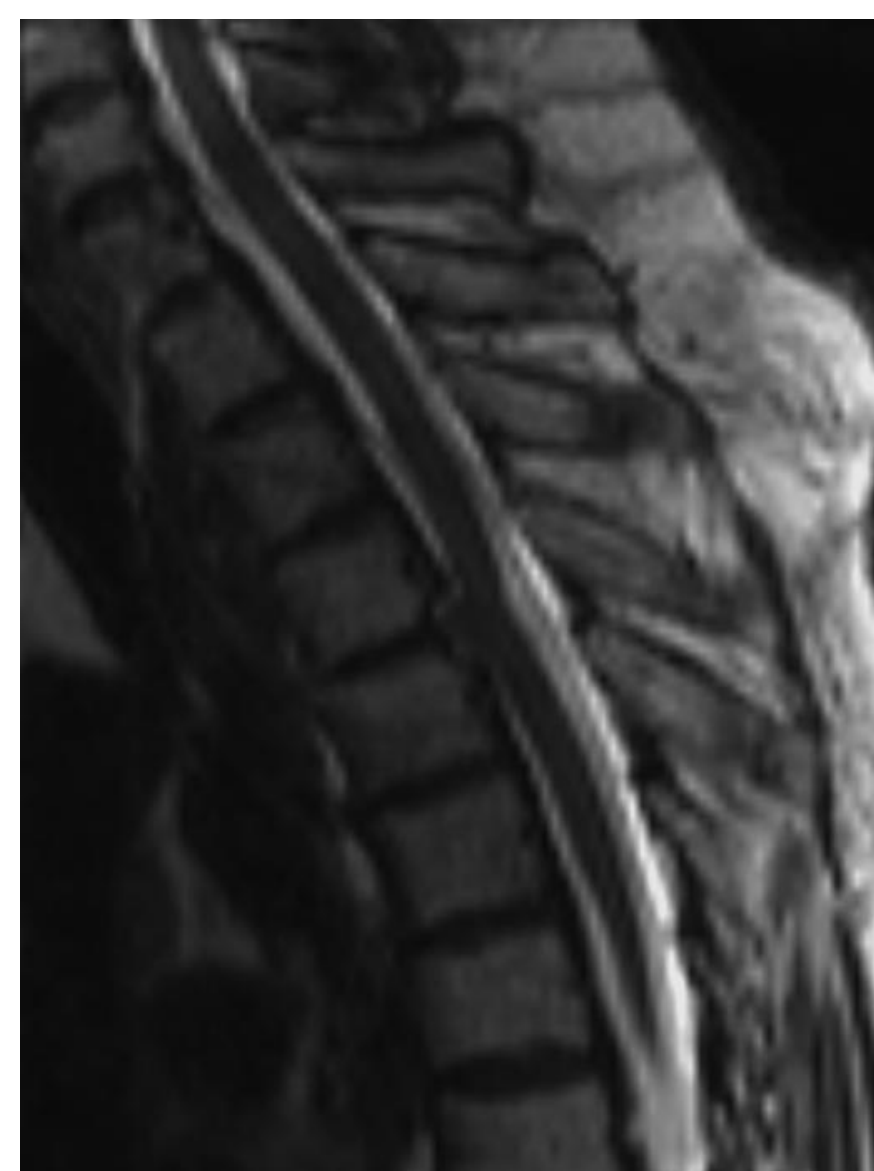

Figure 1. Sagittal constructive interference in steady-state $M R I$ reveals characteristic anterior deviation of the thoracic cord at T3/T4 level.

\section{Spontaneous thoracic spinal cord herniation}

Ashok Srinivasan, MD; Pierre Bourque, MD; and Mayank Goyal, MD, Ottawa, Canada

A 69-year-old woman presented with insidiously progressive and disabling pain in the right leg. There was no history of

Address correspondence and reprint requests to Dr. Mayank Goyal, Department of Diagnostic Imaging, The Ottawa Hospital, Civic Campus, Ottawa, Ontario, Canada; e-mail: mgoyal@ottawahospital.on.ca

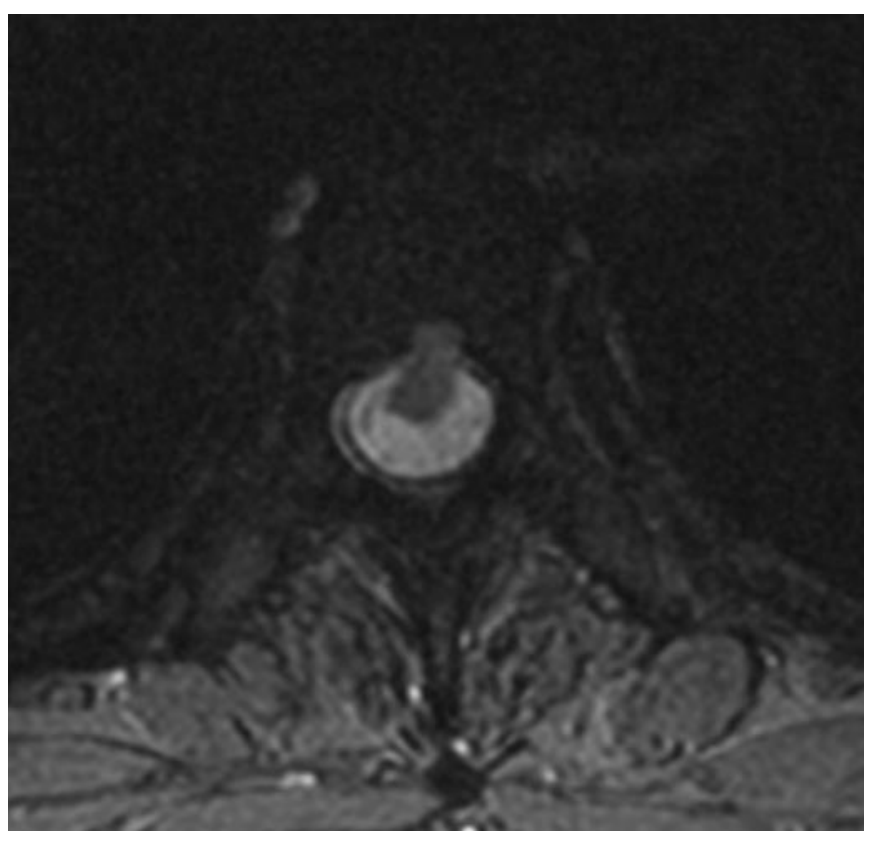

Figure 2. Axial T2*-weighted MRI exquisitely demonstrates the anterior displacement of the cord with dilation of the posterior CSF space. No cord signal abnormality is seen.

trauma or surgery. An examination revealed features suggestive of thoracic level Brown-Sequard syndrome. MRI showed focal anterior deviation of the thoracic cord at T3/T4 level consistent with cord herniation (figures 1 and 2).

Transdural spinal cord herniation is rare and may be spontaneous, post-traumatic, or post-surgical in etiology. The most common site is the thoracic spine where there is spontaneous ventral herniation..$^{1,2}$ Clinical manifestations include Brown-Sequard syndrome (the most common), myelopathy, radiculopathy, or rarely isolated pyramidal signs. Typical imaging features on CT myelogram and MRI include a rotated or displaced cord with dilated CSF space in the opposite direction of the cord displacement. There may also be an associated arachnoid/pseudoarachnoid cyst. ${ }^{1,2}$

1. Ewald C, Kuhne D, Hassler WE. Progressive spontaneous herniation of the thoracic spinal cord: case report. Neurosurgery 2000;46:493-495; discussion 495-496.

2. Watters MR, Stears JC, Osborn AG, et al. Transdural spinal cord herniation: imaging and clinical spectra. AJNR Am J Neuroradiol 1998;19: 1337-1344. 


\title{
Neurology
}

\author{
Spontaneous thoracic spinal cord herniation \\ Ashok Srinivasan, Pierre Bourque and Mayank Goyal \\ Neurology 2004;63;2187 \\ DOI 10.1212/01.WNL.0000140620.32658.0B
}

This information is current as of December 13, 2004

\section{Updated Information \& Services}

References

Subspecialty Collections

Permissions \& Licensing

Reprints including high resolution figures, can be found at: http://n.neurology.org/content/63/11/2187.full

This article cites 2 articles, 0 of which you can access for free at: http://n.neurology.org/content/63/11/2187.full\#ref-list-1

This article, along with others on similar topics, appears in the following collection(s):

\section{All Spinal Cord}

http://n.neurology.org/cgi/collection/all_spinal_cord MRI

http://n.neurology.org/cgi/collection/mri

Information about reproducing this article in parts (figures,tables) or in its entirety can be found online at:

http://www.neurology.org/about/about_the_journal\#permissions

Information about ordering reprints can be found online:

http://n.neurology.org/subscribers/advertise

Neurology ${ }^{\circledR}$ is the official journal of the American Academy of Neurology. Published continuously since 1951, it is now a weekly with 48 issues per year. Copyright. All rights reserved. Print ISSN: 0028-3878. Online ISSN: 1526-632X.

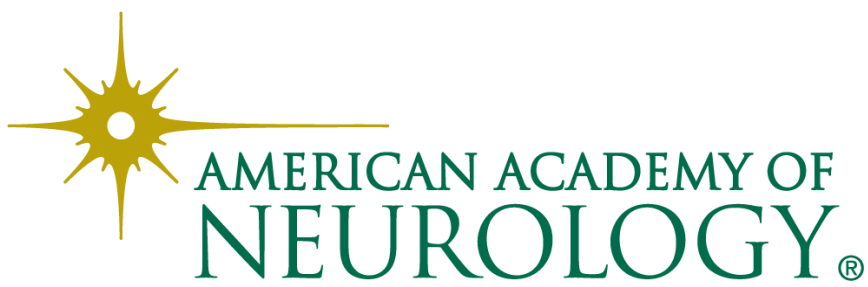

